\title{
INHERITANCE OF RESISTANCE TO Plum pox virus IN THE PROGENY OF THE APRICOT CV. 'HARLAYNE'
}

\author{
P. Pilařová, B. Krška
}

Received: February 18, 2009

\begin{abstract}
PILAŘOVÁ, P., KRŠKA, B.: Inheritance of resistance to Plum pox virus in the progeny of the apricot cv. 'Harlayne'. Acta univ. agric. et silvic. Mendel. Brun., 2009, LVII, No. 5, pp. 243-250

Natural resistance to Plum pox virus (PPV), the agent of sharka disease, is one of the most important traits of interest to stone fruit breeders, although few sources of resistance have been identified. One of the few apricot cultivars which does show resistance, 'Harlayne', was chosen for a study of the genetics of PPV resistance. It was crossed with three different cultivars, two susceptible ('Vestar' and 'Strepet') and one immune ('Orangered'). Four different lines (since there was one reciprocal combination) were established and the Fl crosses were subsequently inoculated with the PPV-M and PPV-D strains by grafting infected buds. A woody indicator Prunus persica 'GF 305' was then also top-grafted onto the plants of three of these Fl populations. The observations of leaf symptoms and accompanying ELISA tests were performed over three, or in one case five, growing seasons and then hybrids were classified accordingly, as either resistant or susceptible. The resistant: susceptible ratios were calculated and compared with expected theoretical ratios using the $\chi^{2}$-test. The ratios of resistant to susceptible plants in the progeny derived from the four apricot crosses are compatible with the hypothesis of three dominant genes being responsible for PPV resistance, with 'Harlayne' being heterozygous for all three genes. However, the possibility that resistance is controlled by just two dominant genes can not be ruled out just yet.
\end{abstract}

PPV, sharka disease, Prunus armeniaca L., segregation ratio, breeding

Apricot belongs to the genus Prunus and is one of the most important species among the stone fruit crops, and sharka disease is considered to be one of the most devastating viral diseases of fruit tree species in the subfamily Prunoidede. It reduces quality by increasing acidity in the fruits and increasing the percentage of deformed fruits, and causes premature fruit drop, so that the economic losses are considerable (Cambra et al., 2006).

Sharka disease is caused by the Plum pox virus (PPV), in the Potyvirus genus of the family Potyviridae. It was first described in Bulgaria (Atanassoff, 1932). Since then, the virus has progressively spread to nearly all the important Prunus growing areas in the world. The virus is non-persistently transmitted over short distances by a number of aphid species, while long distance spread usually occurs as result of the use of infected nursery stock or propagating material.
There are six strains of plum pox virus: PPV-D, PPV-M, PPV-EA, PPV-C, PPV-Rec and PPV-W (Candresse, Cambra, 2006). In the Czech Republic, only the PPV-D, PPV-M and PPV-Rec strains are so far known to be present (Polák, Pívalová, 2005; Gadiou et al., 2008).

The containment of Sharka disease is very difficult, so the development and use of more tolerant, or even resistant, cultivars is one possible solution to this problem. Natural sources of resistance to PPV exist among members of the Prunus genus, but they are not common. Resistance among apricots has been found only in some North American cultivars: 'Goldrich', 'Harlayne', 'Stark Early Orange' ('SEO'), 'Stella' and 'Harcot' (Martínez-Gómez, Dicenta, 2000; Karayiannis et al., 1999). Therefore most conventional breeding programmes very often use one 
of these as a source of resistance in the development of new varieties.

An understanding of the genetic basis of resistance to PPV is critical for its effective utilization in breeding programmes, but different hypotheses about its inheritance have been published. Different reports suggest that the resistance is controlled by either one (Dicenta et al., 2000; Karayiannis et al., 2008), two (Dosba et al., 1991; Moustafa et al., 2001 b; Rubio et al., 2004; Krška et al., 2002) or even three genes (Guillet-Bellanger, Audergon, 2001; Salava et al., 2005).

Apricot breeding has a long tradition at the Faculty of Horticulture in Lednice, and one of the breeding programmes is focussed on the development of cultivars resistant to PPV. Since 1990, different cultivars have been used as donors of resistance (Krška et al., 2006 b). One of them is 'Harlayne', which was classified as resistant in a study by Martínez-Gómez et al. (2003) while Dosba et al. (1992), Polák et al. (1997) and Fuchs et al. (2001) classified it as immune. Therefore this variety was chosen for further study, because little is known about the inheritance of resistance to PPV in its progeny. The aim of this study was to determine how many genes are involved in the inheritance of PPV resistance in 'Harlayne', in order to make current apricot breeding programmes more effective.

\section{MATERIAL AND METHODS}

\section{Plant material}

296 intra-specific hybrids of 4 different Fl populations (summarized in I) were used to study the inheritance of resistance to Plum pox virus. The apricot cultivar 'Harlayne' was used as a donor of resistance in these populations. It was crossed with two susceptible cultivars, 'Vestar' and 'Strepet' (Polák et al., 2003), and an immune cultivar, 'Orangered' (Fuchs et al., 2001). The crosses were made by hand, without isolation of the flowers, after first removing the petals and stamens from the flower buds.

Three year old plants of the 'Harlayne' × 'Strepet', 'Strepet' × 'Harlayne' and 'Orangered' × 'Harlayne' crosses were used for investigation while grafted plants were prepared for evaluating the 'Harlayne' $\times$ 'Vestar' progeny. Scions were taken from 8 year old productive trees and four replicates from each individual were grafted onto apricot seedling rootstocks ('M-VA', mixture). These rootstocks were also used as indicators of susceptibility to PPV.

\section{PPV inoculation}

The grafted plants were inoculated by chip-budding in summer 2003 with the PPV-M and PPV-D isolates, with 2 replicates for each one, where two infected buds were grafted on to the scion part of each replicate. The seedlings were inoculated in the early spring 2006 with the PPV-D isolate. The PPV-M and PPV-D isolates (Poncarová, Komínek; 1998) were provided by the Crop Research Institute in Prague. The plants were pruned immediately after chipbudding to promote the growth of the inoculated bud. The plants which did not show clear sharka symptoms on shoots growing from the inoculum bud were re-inoculated the following year, using the same material and method. Pruning was performed at the beginning of each growing period to induce the development of vigorous new shoots which could then be scored for symptoms of sharka disease.

\section{Evaluation of PPV resistance}

Evaluation was performed at the Faculty of Horticulture in Lednice (MUAF in Brno) in an insectproof screenhouse. In the course of each growing period, shoots originating from both the scion and rootstock of the grafted plants, and shoots from the three year old plants including the inoculum buds, were observed for leaf symptoms at least five times. The PPV incidence was scored individually on each replicate or seedling as follows: 0 - no symptoms; 1 - very light, diffuse spots, symptoms observed in one or two leaves; 2 - diffuse spots bordering leaf veins, symptoms observed in more than two leaves; 3 - diffuse spots and leaf deformation, symptoms observed in most leaves. The mean of the two replicates was used for analysis in the case of the 'Harlayne' × 'Vestar' cross.

In spring 2007 one bud of virus-free Prunus persica 'GF 305' was grafted by chip-budding onto the top of each seedling and plants where the bud did not grow were re-grafted in summer 2007. Shoots growing from the bud were also observed for leaf symptoms, using the same scale.

DAS-ELISA (Clark, Adams; 1977) tests were performed twice during the growing period to confirm the presence or absence of the virus in the plant, using a commercially available polyclonal anti-PPV serum (Bioreba, Switzerland). Leaves originating from the base plant and the grafted woody indicator were taken and tested separately. Seven leaves were collected from each of the symptomless plants for further ELISA tests, and were taken from the middle of

I: Fl populations used to study inheritance of resistance to Plum pox virus

\begin{tabular}{llcc}
\hline \multicolumn{1}{c}{ F1 population } & \multicolumn{1}{c}{ Breeding place } & Year when crossed & Number of hybrids \\
\hline 'Harlayne' × 'Vestar' & Seva-Flora Valtice & 1994 & 59 \\
'Harlayne' × 'Strepet' & Faculty of Horticulture Lednice (MUAF) & 2003 & 110 \\
'Strepet' × 'Harlayne' & Faculty of Horticulture Lednice (MUAF) & 2003 & 44 \\
'Orangered' × 'Harlayne' & Faculty of Horticulture Lednice (MUAF) & 2003 & 83 \\
\hline
\end{tabular}


the branches. In the case where typical symptoms were observed, the leaves with symptoms were collected for the ELISA tests.

PPV infection was evaluated over 5 consecutive growing seasons through visual symptoms and ELISA tests in the case of the 'Harlayne' $\times$ 'Vestar' cross, while the others progeny were evaluated over 3 consecutive growing seasons.

\section{Classification of hybrids}

A hybrid was considered susceptible if it showed symptoms of sharka disease and/or was ELISA-positive in any year of the trial.

\section{Statistical analysis}

The data was analysed using Unistat 5.1.11 software (Unistat Ltd., England). The observed correlations among the data were expressed as an association coefficient or a contingency coefficient. $\chi^{2}$ tests were performed to compare the goodness-of-fit between the observed ratios of resistant to susceptible plants and those expected if inheritance is in accordance with simple Mendelian principles.

\section{RESULTS}

The descendants of four different crosses, in each of which the cultivar 'Harlayne' was used as a donor of resistance, were screened for PPV resistance over 3 or 5 consecutive growing seasons. A few of them showed mild sharka symptoms on the leaves in the same year of inoculation, but after the first period of winter dormancy the PPV symptoms became more marked and the number of plants displaying symptoms increased every year (1).

The correlation between the presence of visible symptoms and a positive reaction in the ELISA test was very high. The coefficient of association ranged from 0.97 ('Harlayne' × 'Strepet') to 0.99 ('Harlayne' × 'Vestar', PPV-D), whereas the correlation between the severity of sharka symptoms in the apricot part and the woody indicator part was lower. Contingency coefficients ranged from 0.54 ('Strepet' × 'Harlayne') to 0.69 ('Harlayne' × 'Strepet').

The results (II and III) clearly show that PPV resistance present in the donor 'Harlayne' was transmitted to its descendants. Within families, the resistant : susceptible ratio was 39:61 in the 'Harlayne' $\times$ 'Strepet' crosses, 53:47 in 'Strepet' × 'Harlayne'

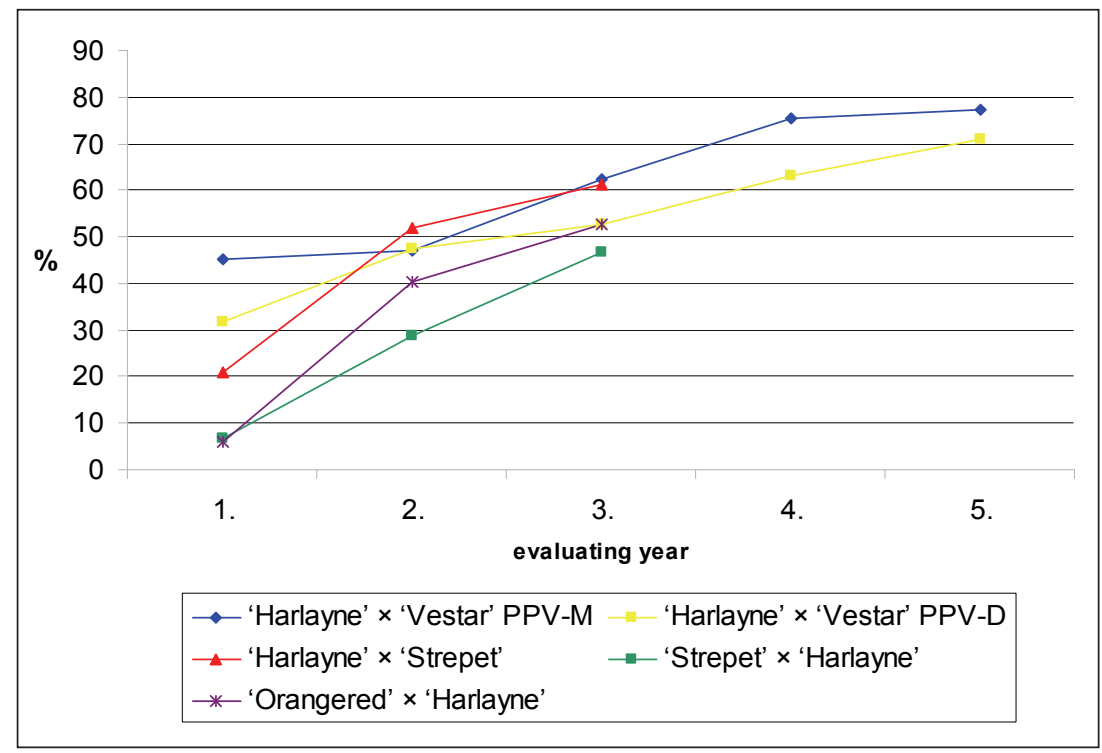

1: Changes over time in \% of plants showing symptoms of sharka disease (after artificial inoculation)

II: Observed and expected ratios of resistant and susceptible plants with regard to the one-gene hypothesis of resistance

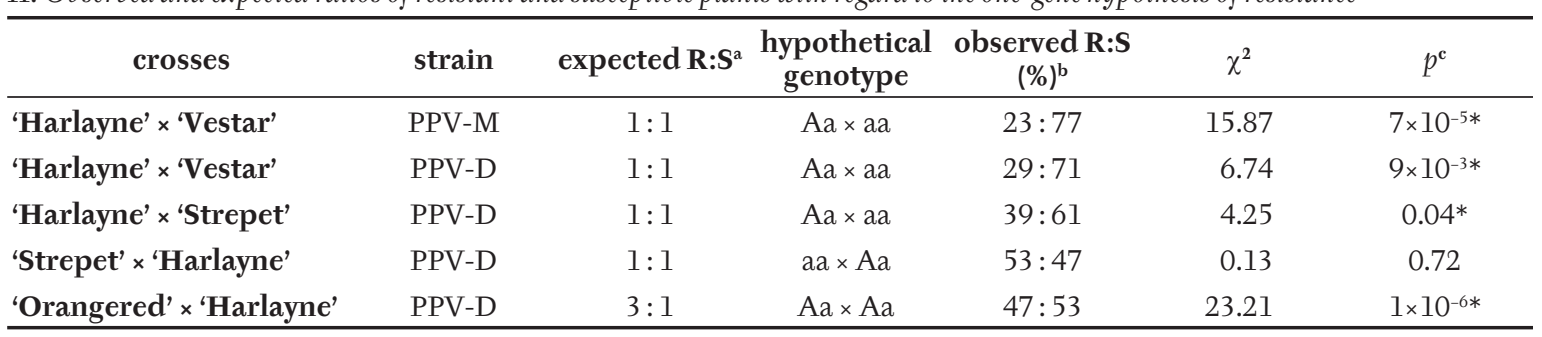

a expected resistant: susceptible ratios for one-gene control of PPV resistance

b observed resistant: susceptible ratios

${ }^{\mathrm{c}}$ probability of tested hypothesis, * indicates ratio statistically different $(p<0.05)$ from expected one 
crosses and 47:53 in 'Orangered' × 'Harlayne' crosses, after three growing seasons. In the case of 'Harlayne' × 'Vestar' it was 23:77 for PPV-M and 29:71 for PPV-D after five growing seasons. These observed ratios were compared with expected theoretical ratios.

It can safely be said that the one-gene hypothesis seems extremely unlikely (II) since the most observed ratios are significantly different from those expected on this basis (II). However, it can be seen that, of all the various possible combinations arising from the two or three gene hypotheses, no clear evidence in support of any one emerges (III). seasons because the number of susceptible plants will almost certainly increase over time. Salava et al. (2005) scored sharka symptoms over 5 and Karayiannis et al. (2008) even 8 consecutive growth periods in their inheritance studies. In contrast, Moustafa et al. (2001 a) regarded only two cycles as being sufficient, because in his study the number of susceptible plants did not vary after the second dormancy. The difference could be caused by the different growing conditions arising when artificial chilling treatment is used.

Prunus persica 'GF305' is widely recommended as a woody indicator and test plant for PPV detection.

III: Observed and expected ratios of resistant and susceptible plants with regard to the two or three-gene hypothesis of resistance

\begin{tabular}{|c|c|c|c|c|c|c|c|}
\hline crosses & strain & Genes $^{a}$ & $\begin{array}{c}\text { expected } \\
\mathbf{R}: \mathbf{S}^{\mathbf{b}} \\
\end{array}$ & Hypothetical genotype & $\begin{array}{c}\text { observed } \\
\text { R:S (\%) }\end{array}$ & $\chi^{2}$ & $p^{\mathrm{d}}$ \\
\hline \multirow[t]{5}{*}{ 'Harlayne' × 'Vestar' } & \multirow[t]{5}{*}{ PPV-M } & \multirow[t]{2}{*}{2} & $1: 3$ & $\mathrm{AaBb} \times \mathrm{aabb}$ & \multirow[t]{5}{*}{$23: 77$} & 0.15 & 0.69 \\
\hline & & & $3: 5$ & $\mathrm{AaBb} \times \mathrm{Aabb}$ & & 4.99 & $0.03 *$ \\
\hline & & \multirow[t]{3}{*}{3} & $1: 7$ & $\mathrm{AaBbCc} \times$ aabbcc & & 4.98 & $0.03 *$ \\
\hline & & & $3: 13$ & $\mathrm{AaBbCc} \times \mathrm{Aabbcc}$ & & 0.53 & 0.47 \\
\hline & & & $9: 23$ & $\mathrm{AaBbCc} \times \mathrm{AaBbcc}$ & & 0.79 & 0.37 \\
\hline \multirow[t]{5}{*}{ 'Harlayne' × 'Vestar' } & \multirow[t]{5}{*}{ PPV-D } & \multirow[t]{2}{*}{2} & $1: 3$ & $\mathrm{AaBb} \times \mathrm{aabb}$ & \multirow[t]{5}{*}{$29: 71$} & 0.32 & 0.57 \\
\hline & & & $3: 5$ & $\mathrm{AaBb} \times \mathrm{Aabb}$ & & 1.19 & 0.28 \\
\hline & & \multirow[t]{3}{*}{3} & $1: 7$ & $\mathrm{AaBbCc} \times \mathrm{aabbcc}$ & & 9.40 & $2 \times 10^{-3 *}$ \\
\hline & & & $3: 13$ & $\mathrm{AaBbCc} \times \mathrm{Aabbcc}$ & & 2.59 & 0.11 \\
\hline & & & $9: 23$ & $\mathrm{AaBbCc} \times \mathrm{AaBbcc}$ & & 0.01 & 0.91 \\
\hline \multirow[t]{5}{*}{ 'Harlayne' x 'Strepet' } & \multirow[t]{5}{*}{ PPV-D } & \multirow[t]{2}{*}{2} & $1: 3$ & $\mathrm{AaBb} \times \mathrm{aabb}$ & \multirow[t]{5}{*}{$39: 61$} & 8.66 & $3 \times 10^{-3 *}$ \\
\hline & & & $3: 5$ & $\mathrm{AaBb} \times \mathrm{Aabb}$ & & 0.06 & 0.80 \\
\hline & & \multirow[t]{3}{*}{3} & $1: 7$ & $\mathrm{AaBbCc} \times \mathrm{aabbcc}$ & & 53.85 & $2 \times 10^{-13 *}$ \\
\hline & & & $3: 13$ & $\mathrm{AaBbCc} \times \mathrm{Aabbcc}$ & & 22.48 & $2 \times 10^{-6 *}$ \\
\hline & & & $9: 23$ & $\mathrm{AaBbCc} \times \mathrm{AaBbcc}$ & & 4.81 & $0,03 *$ \\
\hline \multirow[t]{5}{*}{ 'Strepet' × 'Harlayne' } & \multirow[t]{5}{*}{ PPV-D } & \multirow[t]{2}{*}{2} & $1: 3$ & $\mathrm{AaBb} \times \mathrm{aabb}$ & \multirow[t]{5}{*}{$53: 47$} & 7.51 & $6 \times 10^{-3 *}$ \\
\hline & & & $3: 5$ & $\mathrm{AaBb} \times \mathrm{Aabb}$ & & 1.08 & 0.30 \\
\hline & & \multirow[t]{3}{*}{3} & $1: 7$ & $\mathrm{AaBbCc} \times \mathrm{aabbcc}$ & & 32.02 & $1 \times 10^{-8 *}$ \\
\hline & & & $3: 13$ & $\mathrm{AaBbCc} \times \mathrm{Aabbcc}$ & & 15.35 & $9 \times 10^{-5 *}$ \\
\hline & & & $9: 23$ & $\mathrm{AaBbCc} \times \mathrm{AaBbcc}$ & & 5.10 & $0.02 *$ \\
\hline \multirow{2}{*}{ 'Orangered' × 'Harlayne' } & \multirow[t]{2}{*}{ PPV-D } & 2 & $9: 7$ & $\mathrm{AaBb} \times \mathrm{AaBb}$ & \multirow[t]{2}{*}{$47: 53$} & 1.83 & 0.18 \\
\hline & & 3 & $27: 37$ & $\mathrm{AaBbCc} \times \mathrm{AaBbCc}$ & & 0.63 & 0.43 \\
\hline
\end{tabular}

${ }^{a}$ number of genes

${ }^{\mathrm{b}}$ expected resistant: susceptible ratios for two and three-gene control of PPV resistance

c observed resistant: susceptible ratios

d probability of tested hypothesis, * indicates ratio statistically different $(p<0.05)$ from expected one

\section{DISCUSSION}

Sharka symptoms may show up as much as 3 years after being inoculated, and this demonstrates the dangers of prematurely classifying a hybrid as being resistant (Amenduni et al., 2004). In this study, sharka symptoms were scored for 5 years in one of the crosses and for 3 years in the three others. Even so, the number of susceptible hybrids continued to increase even after the fifth dormancy. Therefore it will be necessary to continue evaluating the progeny that have been observed so far for only 3 growing
It was used in this study for top-grafting onto the descendants of the 'Harlayne' $\times$ 'Strepet', 'Strepet' $\times$ 'Harlayne' and 'Orangered' x 'Harlayne' crosses. After the first dormancy the contingency coefficients of sharka symptom severity on the apricot part and 'GF305' were not high. We expect the coefficients to increase after another cycle of dormancy.

Published studies suggest that resistance to PPV in apricot may be controlled by one, two or three genes. This diversity of opinion may be caused by the small numbers of descendants tested, the length of time 
over which evaluations were made, time of year, environmental conditions or the health and vigour of the plants influencing the expression of symptoms and virus multiplication. It must also be remembered that a plant's reaction to a virus depends not only on the plant but also on the virus, since there are known to be differences in the epidemiological behaviour of the different strains (Candresse, Cambra, 2006).

The apricot cultivar 'Harlayne' has rarely been used to study inheritance of resistance to PPV. Krška et al. (2006 a) studied two lines where 'Harlayne' was crossed with the susceptible cultivars 'Lejuna' and 'Vestar'. He proposed three complementary dominant genes to explain PPV-M resistance. Our results show the difficulty in proving the validity of anyone hypothesis to explain the genetic control of PPV resistance in 'Harlayne'. A hypothesis of two dominant genes, which received the highest probability rating (0.69) in the 'Harlayne' × 'Vestar' progeny using the PPV-M strain, can not be rejected. Although primarily based on an examination of the progeny de- rived from the 'Orangered' × 'Harlayne' cross, the hypothesis of three dominant genes fits the results better, if 'Harlayne' is assumed to be heterozygous for all three genes. Furthermore, PPV resistance in 'Stark Early Orange', another cultivar resistant to PPV, also involves at least 3 dominant heterozygous genes (Guillet-Bellanger, Audergon, 2001) and, interestingly, the behaviour of the GFP-tagged PPV in both these two cultivars was shown to be similar by Ion-Nagy et al. (2006).

The fact that plants with different degrees of susceptibility or resistance can be found, and that this can be measured quantitatively, appears to support the hypotheses proposed here about the oligogenic inheritance of resistance to PPV. In addition, the results obtained from a separate study involving quantitative trait analysis of resistance to PPV in the 'Harlayne' $\times$ 'Vestar' cross and in which two regions were identified as being involved in resistance to PPV-D and three for PPV-M, lend further support to this theory (Pilařová et al., submitted).

\section{SUMMARY}

The aim of this study was to improve knowledge of the inheritance of PPV resistance in apricots for use in future breeding programmes. Four different Fl progeny, where the cultivar 'Harlayne' was used as a donor of resistance, were studied. The plants from these four lines were inoculated with the PPV-M and PPV-D strains. The scoring of leaf symptoms was performed at least five times in each growing season. DAS-ELISA tests were performed twice each season to confirm the presence or absence of the virus in the plants. The presence or absence of PPV infection was monitored over the following 3 , in some cases 5, consecutive growing seasons. If the hybrid plants showed no sharka symptoms and the ELISA test was negative throughout the whole period of evaluation, they were considered to be resistant. The first, mild symptoms of sharka disease appeared in the same year as the inoculation, but the incidence of PPV was much higher after the first winter dormancy. Subsequently, the number of plants classified as susceptible increased every year until the fifth year following inoculation. Association coefficients between the presence of symptoms and a positive ELISA test were high. After the three or five years of evaluation, the ratio of resistant to susceptible plants in the $\mathrm{Fl}$ progeny was calculated for each line. Within lines, the resistant:susceptible ratio was 39:61 in 'Harlayne' $\times$ 'Strepet', 53:47 in 'Strepet' × 'Harlayne' and 47:53 'Orangered' × 'Harlayne' after three growing seasons. In the case of 'Harlayne' × 'Vestar' it was 23:77 for PPV-M and 29:71 for PPV-D after five growing seasons. These ratios were compared with theoretical ones using the $\chi^{2}$-test. The results obtained from this study of four apricot crosses fit the hypothesis of three dominant genes to explain the inheritance of PPV resistance ( $p=0.91$ and $p=0.43$, the highest $p$ in 'Harlayne' $\times$ 'Vestar', PPV-D and 'Orangered' $\times$ 'Harlayne' progeny), with 'Harlayne' being heterozygous for all three genes. However, the alternative hypothesis of just two dominant genes can not be completely rejected just yet ( $\mathrm{p}=0.8$ and $\mathrm{p}=0.69$, the highest $\mathrm{p}$ in 'Harlayne' × 'Strepet' and 'Harlayne' × 'Vestar', PPV-D, progeny).

\section{SOUHRN}

Dědičnost rezistence meruněk k viru šarky švestky u potomstev odrůdy 'Harlayne'

Cílem této práce bylo určit počet genů rozhodujících o dědičnosti rezistence meruněk k šarce švestek, které by mohly být využity v dalších šlechtitelských plánech. Za tímto účelem byla vybrána čtyř̀i potomstva, u nichž byla odrůda 'Harlayne' použita jako zdroj rezistence k tomuto viru. Jedinci těchto potomstev byli inokulováni kmeny PPV-M a PPV-D.

Pozorování symptomů na listech bylo prováděno minimálně pětkrát za vegetační sezonu. Pro potvrzení přítomnosti nebo absence viru šarky švestky v rostlinách byl použit DAS-ELISA test, který byl prováděn dvakrát během vegetační sezony. Př́itomnost infekce viru šarky švestky byla hodnocena po dobu tří nebo pěti vegetačních sezon. Na základě získaných výsledků během pozorování a testo- 
vání byli jedinci rozděleni na rezistentní a citlivé. Za citlivé byli považování ti, na jejichž listech se během doby hodnocení ukázaly příznaky šarky a/nebo výsledky ELISA testu byly pozitivní.

První mírné příznaky šarky se objevily již v roce inokulace, ale síla příznaků byla mnohem větší po první dormanci. Počet citlivých jedinců přibýval každý rok a to i pátým rokem po inokulaci.Závislost př́tomnosti symptomů a pozitivního výsledku ELISA testu byla vysoká.

Po třech nebo pěti letech hodnocení byl vypočítán poměr mezi rezistentními a citlivými jedinci v jednotlivých populacích. V populacích byl poměr rezistentní: citlivý po třech letech hodnocení následující ‘Harlayne' × 'Strepet' 39:61, 'Strepet' × 'Harlayne' 53:47, 'Orangered' × 'Harlayne' 47:53, v př́padě populace 'Harlayne' × 'Vestar' po pěti letech 23:77 pro kmen PPV-M a 29:71 pro kmen PPV-D. Tyto poměry byly porovnány pomocí $\chi^{2}$-testu s teoretickými. Ze získaných výsledků čtyř potomstev nelze jednoznačně určit, zda rezistenci k šarce švestky kontrolují dva $(p=0.8$ a p =0.69, nejvyšší hodnoty $p$ u potomstva 'Harlayne' × 'Strepet' a 'Harlayne' × 'Vestar', PPV-D) nebo tři ( $p=0.91$ a p = 0.43, nejvyšší hodnoty p u potomstva 'Harlayne' × 'Vestar', PPV-D a 'Orangered' × 'Harlayne') dominantní geny.

PPV, šarka švestky, Prunus armeniaca L., štěpný poměr, šlechtění

Special thanks are due to Malcolm Russell for his help with the final draft of the English translation. This work was partly supported by project 9/2008/591 from the Grant Agency of Mendel University of Agriculture and Forestry and by the SharCo FP7 Small collaborative research project, number 204429.

\section{REFERENCE}

AMENDUNI, T., BAZZONI, A., MINAFRA, A. and SAVINO, V., 2004: Evaluation of the susceptibility of seedlings from apricot crosses to the Marcus strain of plum pox virus. Acta Hort, 657: 305-308. ISSN 0567-7572

ATANASSOFF, D., 1932: Plum pox: a new virus disease. Yearbook University of Sofia, Faculty of Agriculture, 11: 49-60 In: LÓPEZ-MOYA, J. J., FERNÁNDEZ-FERNÁNDEZ,M.R., CAMBRA,M. and GARCÍA, J. A., 2000: Biotechnological aspects of plum pox virus. Journal of Biotechnology, 76: 121-136. ISSN 0168-1656

CAMBRA, M., CAPOTE, N., MYRTA, A. and LLÁCER, G., 2006: Plum pox virus and the estimated costs associated with sharka disease. EPPO Bull, 36: 202-204. ISSN 1365-2338

CANDRESSE, T. and CAMBRA, M., 2006: Causal agent of sharka disease: historical perspective and current status of Plum pox virus strains. EPPO Bull, 36: 239-246. ISSN 1365-2338

CLARK, M. F. and ADAMS, A. N., 1977: Characteristics of the micro-plate method of enzyme-linked immunosorbent assay for the detection of plant viruses. J Gen Virol, 34, 3: 475-483. ISSN 1465-2099

DICENTA, F., MARTÍNEZ-GÓMEZ, P., BURGOS, L. and EGEA, J., 2000: Inheritance of resistance to Plum pox potyvirus (PPV) in apricot, Prunus armeniaca. Plant Breed, 119: 161-164. ISSN 1439-0523

DOSBA, F., DENISE, F., AUDERGON, J. M., MAISON, P. and MASSONIE, G., 1991: Plum pox virus resistance of apricot. Acta Hort, 293: 569-579. ISSN 0567-7572

DOSBA, F., ORLIAC, S., DUTRANNOY, F., MAISON, P., MASSONIÉ, G. and AUDERGON, J. M., 1992: Evaluation of resistance to plum pox virus in apricot trees. Acta Hort, 309: 211-220. ISSN 0567-7572
FUCHS, E., GRÜNTZIG, M. and ERNST, I., 2001: Comparison of apricot genotypes with different resistence level to plum pox virus (PPV). Acta Hort, 550: 103-106. ISSN 0567-7572

GADIOU, S., ŠAFÁŘOVÁ, D. and NAVRÁTIL, M., 2008: Genetic variability of Plum pox virus isolates in the Czech Republic. Eur J Plant Pathol, (in press). doi: 10.1007/s10658-008-9272-7

GUILLET-BELLANGER, I. and AUDERGON, J. M., 2001: Inheritance of the Stark Early Orange apricot cultivar resistance to Plum pox virus. Acta Hort, 550: 111-116. ISSN 0567-7572

ION-NAGY, L., LANSAC, M., EYQUARD, J. P., SALVADOR, B., GARCIA, J. A., LE GALL, O., HERNOULD, M., SCHURDI-LEVRAUD, V. and DECROOCQ, V., 2006: PPV long-distance movement is occasionally permitted in resistant apricot hosts. Virus Research, 120: 70-78. ISSN 0168-1702

KARAYIANNIS, I., THOMIDIS, T. and TSAFTARIS, A., 2008: Inheritance of resistance to Plum pox virus in apricot (Prunus armeniaca L.). Tree Genetics 6 Genomes, 4: 143-148. ISSN 1614-2942

KRŠKA, B., SALAVA, J. and POLÁK, J., 2006 a: Breeding for Plum pox virus resistant apricots (Prunus armeniaca L.) in the Czech Republic. EPPO Bull, 36: 330-331. ISSN 1365-2338

KRŠKA, B., SALAVA, J., POLÁK, J. and KOMÍNEK, P., 2002: Genetics of resistance to plum pox virus in apricot. Plant Prot Sci, 38: 180-182. ISSN 1212-2580

KRŠKA, B., VACHU゚N, Z. and NEČAS, T., 2006 b: The apricot breeding programme at the Horticulture Faculty in Lednice. Acta Hort, 717: 145-146 ISSN 0567-7572

MARTÍNEZ-GÓMEZ, P. and DICENTA, F., 2000: Evaluation of resistance of apricot cultivars to a Spanish isolate of plum pox potyvirus (PPV). Plant Breed, 119: 179-181. ISSN 1439-0523 
MARTÍNEZ-GÓMEZ, P., DICENTA, F. and EGEA, J., 2003: Effect of a traditional control method (tree removal) on the spread of sharka in an apricot orchard in Southeastern Spain. Phytopathol. Mediterr, 42: 161-166. ISSN 0031-9465

MARTÍNEZ-GÓMEZ, P., RUBIO, M. and DICENTA, F., 2003: Evaluation of resistance to plum pox virus of North American and European apricot cultivars. HortScience, 38: 568-569. ISSN: 0018-5345

MOUSTAFA, T. A., BADENES, M. L., MARTÍNEZCALVO, J. and LLÁCER, G., 2001 b: Studies on Plum pox (sharka) resistance in apricot. Acta Hort, 550: 117-120. ISSN 0567-7572

MOUSTAFA, T. A., BADENES, M. L., MARTÍNEZCALVO, J. and LLÁCER, G., 2001 A: Determination of resistance to sharka (plum pox) virus in apricot. Scientia Hort, 91: 59-70. ISSN 0304-4238

PILAŘOVÁ, P., MARANDEL, G., DECROOCQ, V., SALAVA, J., KRŠKA, B. and ABBOTT, A. G.: Quantitative trait analysis of resistance to Plum pox virus in the apricot Fl progeny 'Harlayne' × 'Vestar'. Submitted

POLÁK, J. and PÍVALOVÁ, J., 2005: Sporadic distribution of Plum pox virus $\mathrm{M}$ strain in natural sources in the Czech Republic. Hort Sci, 32, 3: 85-88. ISSN 0862-867X
POLÁK, J., OUKROPEC, I., KOMÍNEK, P., KRŠKA, B. and BITOOVÁ, M., 1997: Detection and Evaluation of resistance of apricots and peaches to plum pox virus. Journal of Plant Diseases and Protection, 104, 5: 466-473. ISSN 1861-3829

POLÁK, J., OUKROPEC, I., KRŠKA, B., PÍVALOVÁ, J. and MILLER, W., 2003: Difference in reactions of apricot and peach cultivars to Plum pox virus: serological and symptomatological evaluation. Hort Sci, 30, 4: 129-134. ISSN 0862-867X

PONCAROVÁ, Z. and KOMÍNEK, P., 1998: Restriction fragment length polymorphism differentiation of plum pox virus isolates. Acta Virol, 42, 4: 268-269. ISSN 1336-2305

RUBIO, M., MARTÍNEZ-GÓMEZ, P., DICENTA, F. and AUDERGON, J. M., 2004: Testing of genetic control hypothesis for Plum pox virus resistance in apricot. Acta Hort. 663: 265-267. ISSN 0567-7572

SALAVA, J., POLÁK, J. and KRŠKA, B., 2005: Oligogenic inheritance of resistance to Plum pox virus in apricots. Czech J Genet Plant Breed, 41: 167-170. ISSN 1212-1975 
